\title{
Edith Stein - "Great Daughter of Israel and Carmel”, Searching for the Truth Every Day
}

\begin{abstract}
Edith Stein was born in a traditional religious Jewish family. In her youth, she stopped praying and lost her faith in God. She was, however, very faithful in searching for the truth, which had become her life's passion. First, the article presents various definitions of truth. Then it deals with phenomenological methods of discovering the truth about man, which were characteristic of Edith Stein. Finally, it shows her discovery of the God of Love, who pulled her towards mystical union in the spirituality of Carmel. St. Teresa Benedicta of the Cross (Edith Stein) died in the concentration camp at Auschwitz experiencing the mystery of the Cross of Christ and sacrificing herself for her nation.
\end{abstract}

\section{Keywords}

Truth; God; Love; Cross; Daughter of Israel; Carmel.

Man seeks what is 'good', but he does not always associate that search with the truth. His subjective understanding of the good often disconnects it from the truth, thus actually leading him to cease to seek the truth.

Edith Stein was a woman who always held these two realities together. It is, therefore, no wonder that her great words are written on the plinth of her monument in Cologne: "He who seeks the truth seeks God, even if he does not know it". Let us undertake a scholarly reflection on the truth, something extraordinarily important in St. Edith Stein's life. The quest for truth led that "eminent daughter of Israel and Carmel ${ }^{1 "}$ to the outstanding development of her humanity.

1 This characteristic term to determine the character of Edith Stein was used by Pope John Paul II in his homily during the beatification ceremony in Cologne. John Paul II, Świadectwo błogosławionej 
People living in contemporary Europe are often guided by a notion of the 'good', understood as the achievement of temporal prosperity. This trend has actually already been present for at least two hundred years, as Cardinal Joachim Meisner rightly pointed out in his homily on the occasion of the $70^{\text {th }}$ anniversary of St. Edith Stein's death in Auschwitz. “... Europe tries to make the norm of conduct in this world neither eternal life, heaven, nor God"2. There is, of course, appeal to eternal values, which "are supposed to save man - albeit only then when he places them into the present, among people, in society. By thus acting, the economy, in the meantime, becomes the reference for all values, with its cultural work 'capital' as the Bible of a new materialism. What guides the thoughts and lives of contemporary man is no longer the difference between 'true' and 'untrue' but whether or not something sells. A faith built on such foundations will destroy itself. The witness of St. Edith Stein's life shows this unambiguously"3.

Truth ought to be the determinant of human functioning in both individual as well as social life. Society should be based on real truth, as grasped by concrete individuals.

For Edith Stein, such an understanding of truth was the basis of being human. She demonstrated this by her life, and shows us, to this day, the way out of the dictatorship of relativism, leading to the discovery of real human dignity.

\section{Concepts of the Truth}

In order to understand Edith Stein's discourse on the truth better, let us first recall four characteristic concepts of this question: the classic, the coherent, the pragmatic, and the sociological.

The first - the classic one - is the oldest and most important. It has, at its root, a commonsense definition: the compatibility of judgments, beliefs, and statements with reality. In this definition, the aspect of existence is in the foreground: something exists or does not exist. We are dealing with the truth

Edyty Stein, siostry Benedykty od Krzyża - męczennicy, Homily delivered during the beatification of Edith Stein in Cologne (05/01/1987), 9. http://cdim.pl/pl/edukacja/zasoby-edukacyjne/teksty/52teksty-kocioa-katolickiego/74-1987-05-01-jan-pawe-ii-beatyfikacja-edyty-stein (06.08.2014).

2 J. Meisner, Homilia z okazji 70. rocznicy śmierci św. Edyty Stein w Auschwitz (08/09/2012), Education, Centre for Dialogue and Prayer in Auschwitz, www.cdim.pl (05.08.2014).

3 J. Meisner, Homilia z okazji 70. rocznicy śmierci św. Edyty Stein w Auschwitz (08/09/2012), Education, Centre for Dialogue and Prayer in Auschwitz, www.cdim.pl (05.08.2014). 
if the mind states that fact ${ }^{4}$. That definition is thus called existential because of the distinctive aspect of existence. Others call it 'the correspondence theory of truth' because the essence of truth is its compatibility or a point of reference. The Jewish philosopher Issac Ben Salomon was the author of this formulation of the truth. It was not however, in the final analysis, original, because that definition of truth can already be found in the writings of Aristotle ${ }^{5}$, which St. Thomas Aquinas cited in Latin: Veritas est adaequatio intellectus et rei, secundum quod intellectus dicit esse, quod est, et non esse, quod non est [Truth is the adequacy of the intellect and reality, according to which the intellect says that what is is, and what is not is not $]^{6}$.

Truth is correspondence. The mind affirms, it does not construct reality. "Objective reality defines the truth, and the human subject is responsible for its comprehension", as philosopher Wojciech Chudy rightly observed in his lecture on truth. In other words, the intellect reads reality. Its task is to read reality as it is.

Furthermore, truth is a characteristic of the statement. The judgment may, in fact, be true or false. A true statement does not contain the whole truth about a given phenomenon. It deals with only a certain angle of reality, its concrete aspect.

The classic concept of truth guarantees the stability of truth. The adoption of this concept of truth "guarantees the avoidance of far-reaching deformations of the knowledge of reality" .

The second concept of truth is 'the coherence concept', which rests upon continuous and logical homogeneity. According to this concept, truth is expressed in thoughts that constitute a harmonious, cohesive whole. The coherence concept derives from the thought of Poincaré and Quine. According to this concept,

4 In his article analyzing the responses of Kazimierz Ajdukiewicz, Marcin Będkowski notes that the perception of reality and facts sometimes varies. One can see this in the formulation of various theories. Subjective idealism might be one example. "The hypothesis - a very likely one - is that bodies do exist even though they are not perceived. Subjective idealism solves this problem, however, by assuming an a priori argument which identifies existence with being perceived”. M. Będkowski, Kazimierz Ajdukiewicz jako krytyk idealizmu subietywnego [Kazimierz Ajdukiewicz as a Critic of Subjective Idealism], "Edukacja Filozoficzna” 55 (2013), p. 36.

5 Cf. A.B. Stępień, Wstęp do filozofii [Introduction to Philosophy], Lublin 1976, p. 122-25.

6 St. Thomas Aquinas, cited in W. Chudy, Filozofia klamstwa [The Philosophy of the Lie], Warsaw 2003, p. 23.

7 W. Chudy, Filozofia ktamstwa [The Philosophy of the Lie], Warsaw 2003, p. 24.

8 W. Chudy, Filozofia klamstwa [The Philosophy of the Lie], Warsaw 2003, p. 24. 
science (referring to mathematics, geometry, computer science, theoretical physics and molecular biology) is a kind of grid of concepts, judgments, and statements imposed on the world. According to the coherence concept, a given scientific theory is true when it clearly demonstrates a sensible whole that, at the same time, accounts for the reality well. When, on the other hand, a theory does not explain reality well it means that, in this instance, we find some lacunae in it, so that the theory is false.

The coherence concept works in the case of the sciences. Its problem appears, however, when we apply it to philosophy and to man. The reason for this is the relativism that this concept introduces 9 .

The third of the concepts of truth previously mentioned is the pragmatic concept, according to which the truth of a thought depends upon its utility in action. Its author was the American philosopher, William James. He associated truth with religious elements and faith, and claimed that people adopt some superstitions and beliefs as true in their life practices. They accept them "on faith". This happens, he says, because they afford, in some cases, a sense of security and self-confidence. They are true because they fulfill the function of a kind of fetish. This concept can be justified from a psychological point of view but it must be emphasized, however, that it has little in common with an objective sense of $\operatorname{truth}^{10}$.

Finally, the last of the concepts of truth mentioned above, one that is in wide circulation is the sociological concept. According to that concept, truth is what the majority recognizes. This concept implies social relativism, according to which there is no single truth for everyone. The sociological concept is the truth of power. Truth is frequently created by the mass media, which achieves its goal by actions manipulating the recipient. As Wojciech Chudy rightly pointed out, this is the problem of democracy: "in wanting to be authentic, it must be built not on the truth of the majority but on real truth that is, however, comprehended by the majority of individual subjects"11.

9 Cf. W. Chudy, Filozofia ktamstwa [The Philosophy of the Lie], Warsaw 2003, p. 24-25.

${ }^{10}$ Cf. W. Chudy, Filozofia kłamstwa [The Philosophy of the Lie], Warsaw 2003, p. 25.

${ }^{11}$ W. Chudy, Filozofia ktamstwa [The Philosophy of the Lie], Warsaw 2003, p. 27; Cf. M. Enders, J. Szaif (eds.): Die Geschichte des philosophischen Begriffs der Wahrheit. Berlin 2006; M. Adamczyk, Edith Steins Weg zur Wahrheit, „Poznańskie Studia Teologiczne” 27 (2013), p. 97-99. 


\section{The Truth about Man}

Edith Stein was born on September 12, 1891 in Wrocław (which then belonged to Germany) to a Jewish merchant family. Her father, unfortunately, died early (she was 9 months old and the eleventh child in the family), hence her mother, Augustine, was forced to raise seven children (four died) while running a timber business. She did all this as a devout Jew, drawing strength from a deep and living faith. Although her mother provided her with a good example as a believer, Edith nevertheless consciously rejected her faith in her youth $^{12}$.

Her older brothers' attitudes were, in this regard, greatly influential. Edith herself described the atmosphere towards religious practices that prevailed in her home: "Religious cult in general lost its value because only my mother and the younger children practiced it. My brothers, who should have led prayers in lieu of my deceased father, did so disrespectfully. When my eldest brother was absent and the younger one had to assume the role as head of household, it was clear that he mocked it all"13.

Edith was, however, a person full of lofty ideals and gifted with an extraordinary intellect. She sought the truth as such in her life. She also sought the truth about man. She asked who man is and who he ought to be. It could be said that these questions became the point of departure for her life search. Uncovering the truth became her lifelong passion.

Wanting to find answers to those basic questions, Edith Stein began her university studies, first in psychology in her native Wrocław. Her further quest for the truth led her to undertake studies in philosophy in Göttingen. Her mentor was Professor Edmund Husserl, under whom she later became a teaching assistant. She also wrote her doctoral dissertation under his direction. In it, she undertook the unusually interesting study of human empathy, studying its possibilities in the question of understanding other people ${ }^{14}$. That method,

${ }^{12}$ Cf. Teresa Renata of the Holy Spirit (ed.), Edyta Stein, filozof i karmelitanka, Paris 1987, p. 11. See. St. Teresa Benedicta of the Cross (Edith Stein), Dzieje pewnej rodziny żydowskiej [The History of a Certain Jewish Family], Kraków 1995, p. 25-71.

${ }^{13}$ E. Stein, Światłość w ciemności [Light and Darkness], vol. 1, Kraków 1977, p. 56.

${ }^{14}$ See E. Stein, O zagadnieniu wczucia [On the Question of Empathy], Kraków 1988, p. 121. In her reflections the author draws attention to the fact that the world in which man lives together with his subjective Self is not only the world of physical bodies. There are, in fact, other subjects having experiences in it. Moreover, Edith Stein notes the existence of the phenomenon of mental 
together with her openness to truth, led her to subsequent fascinating discoveries in the later stages of her life.

Edith Stein's theses regarding man seem to be obvious but they confirm, however, what Anna Kotłowska rightly observed in her article: "the possibility of achieving a knowledge of man that is certain, one that is so available but yet in itself either unconscious or undetected as relevant to existential considerations"15. The academic search contained in her doctoral dissertation confirms the thesis that her scholarly investigations were a consistent quest for the truth about man, whom she always regarded as a unity of body, soul, and spirit. Roman Ingarden, who was Stein's friend from the time of her studies in Göttingen, wrote years later that hers was a search for an answer to the question: "what is the structure of man, to which I have access, among other things, through empathy?"16.

In her dissertation, Stein first focuses on the phenomenon of the human body, which always remains a mystery for her. Using phenomenological analysis, discussion, and interpretation, she attempts to explain various conditions that affect the human body. When she writes about the body in her dissertation, she has in mind two meanings for the same concept. It is, on the one hand, the body in its physical and material sense, but on the other hand it is the body as a living being ${ }^{17}$. The human body is recognized as unique matter which in its essence is incomparable. The existence of the human "I" is inscribed in its uniqueness, something which Stein understands as: "I am that through its own reflections, through careful, introspective observation, wants to reach the truth about man, about his existence and about the meaning or at least the relative purpose of his being"18. The individual "I" invoked here is the first and most basic constitutive element of the personal human being. That "I" acquires his identity through confrontation with another individual "I." Man needs these relationships with the other to understand, at least partially, his existence. That

life in another subject. To grasp how another person experiences it, you need - in her opinion - an act of empathy.

${ }^{15}$ A. Kotłowska, Fenomenologiczna myśl antropologiczna Edyty Stein [The Phenomenological Anthopology of Edith Stein], "Fenomenologia" 8 (2010), p. 64.

${ }^{16}$ R. Ingarden, O badaniach filozoficznych Edyty Stein [On the Philosophical Research of Edith Stein], in: E. Stein, O zagadnieniu wczucia [On the Question of Empathy], Kraków 1988, p. 177.

${ }^{17}$ Cf. E. Stein, O zagadnieniu wczucia [On the Question of Empathy], Kraków 1988, p. 61.

18 A. Kotłowska, Fenomenologiczna myśl antropologiczna Edyty Stein [The Phenomenological Anthopology of Edith Stein], p. 66. 
confrontation also allows him to understand that he is different from other men, that he is not the same as them. The experience also allows him to understand the truth that he is a being that is open to the world and to other people as well as to become conscious of the differences that exist between "I" and "you". That, in turn, constitutes the chance to enter into the depths of his being and define the clear and necessary boundary between "I" and "you"19.

Man has a physical body which is capable of knowing because it is equipped with those physical capabilities. He does this by means of external observations. Having analyzed this strand of study, Anna Kotłowska concludes: "Perceiving one's own body is (...) a special kind of perception, entitled and available only to the one who perceives, because the perceived is at the same time the perceiver" 20 .

Edith Stein further concluded that the physical condition of the human body affects how it experiences feelings. There is a relationship, she notes, between the state of the body and experiences flowing in from outside. A healthy body, in contrast to a tired and sick one, allows for experiencing feelings properly ${ }^{21}$.

A person who has certain internal experiences expresses them through external signs which can, however, be misinterpreted by external observers. That is why Edith Stein proposes a phenomenological analysis through the use of empathy ${ }^{22}$.

Przemysław Biela, in one of his interesting articles, undertook a scholarly reflection on the ideas that Edith Stein presented in her doctoral dissertation. Among other things, he focused attention on the next important question, i.e., what is the constitutive element of man? He wrote: "It is, in Stein's usage, the substantial soul ( $p$ syche, German Seele) - the foundation of mental life that enlivens and humanizes the physical body. (...) It is one of many bodies in the natural world but, at the same time, is the carrier of mental life. Its unity with the soul as a psycho-physical entity does not exist without the "I". Through the body and the spirit, man belongs both to the natural and spiritual worlds, which are identical and real" ${ }^{23}$. Man is therefore a person because of the spirit. This

${ }^{19}$ Cf. A. Kotłowska, Fenomenologiczna myśl antropologiczna Edyty Stein [The Phenomenological Anthopology of Edith Stein], p. 66.

${ }^{20}$ A. Kotłowska, Fenomenologiczna myśl antropologiczna Edyty Stein [The Phenomenological Anthopology of Edith Stein], p. 67.

${ }^{21}$ Cf. E. Stein, O zagadnieniu wczucia [On the Question of Empathy], Kraków 1988, p. 71.

22 Cf. E. Stein, O zagadnieniu wczucia [On the Question of Empathy], Kraków 1988, p. 71-77.

${ }^{23}$ P. Biela, Einfühlung jako dialogiczność personalizmu fenomenologicznego Edith Stein [Empathy as Dialogue in Edith Stein's Phenomenological Personalism], „Czasopismo Filozoficzne” 
spiritual sphere constitutes man as a person. He thus differs from the world of plants and animals ${ }^{24}$. Man as a person, who is also made of a personality, is a value in himself. However, in Stein's view, man should develop through the development of his personality, undertaking life activities by being open at the same time to the axiological dimension. Thus he who "does not feel values, but acquires all his feeling through exposure to others, cannot experience "himself", cannot become a personality but, at most, is an illusory image" 25 . As a spiritual being, man requires constant development built on a search for values and on knowing himself ${ }^{26}$. This takes place at the intersection of the material and spiritual because there occurs, in that area, a ceaseless dialectic that reveals itself on the threshold of the transition from the spiritual to physical worlds, and vice versa. In practice, it is man who. on the one hand, tames the space of the world in which he lives by putting the materialized mark of his spirit on it while, on the other hand, he allows that world to leave its mark on him $^{27}$. To sum it up: " "The event of man' takes place in the transition from the world of nature to the world of culture" 28 .

In his article on phenomenological personalism, Andrzej Półtawski recalled the response of Philbert Secretan, who fits perfectly into the reflection on the search for the truth about man in the thought of Edith Stein. He described her viewpoint as personalism, as the encounter of "man with his dignity, which he himself frequently does not respect" ${ }^{29}$. Furthermore, in his view, the

4/5 (2009), p. 116-117.

${ }^{24}$ Cf. F. Gruszka, Osoba i jej rozwój-wedtug Edyty Stein [Man and His Development According to Edith Stein], in: K. Holeksa, E. Leśniewska, S. Leśniewski (eds.), Uderz o kamień a wytryśnie madrość. Rzecz o Edycie Stein [Strike a Stone and It Yields Wisdom: On Edith Stein], Kraków 2002, p. 89.

${ }^{25}$ F. Gruszka, Osoba i jej rozwój - wedtug Edyty Stein [Man and His Development According to Edith Stein], in: K. Holeksa, E. Leśniewska, S. Leśniewski (eds.), Uderz o kamień a wytryśnie madrość. Rzecz o Edycie Stein [Strike a Stone and It Yields Wisdom: On Edith Stein], Kraków 2002, p. 145.

${ }^{26}$ Cf. P. Biela, Einfühlung jako dialogiczność personalizmu fenomenologicznego Edith Stein [Empathy as Dialogue in Edith Stein's Phenomenological Personalism], p. 117.

${ }^{27}$ Cf. A. Kotłowska, Fenomenologiczna myśl antropologiczna Edyty Stein [The Phenomenological Anthopology of Edith Stein], p. 76.

${ }^{28}$ J. Machnacz, Odnaleźć siebie, drugiego, Boga. Antropologia Edyty Stein [To Find Self, the Other, God: The Anthropology of Edith Stein], in: J. Patera (ed.), Odnaleźć siebie, drugiego, Boga. Antropologia Edyty Stein [To Find Self, the Other, God: The Anthropology of Edith Stein], Wrocław 2005, p. 23.

${ }^{29}$ P. Secretan, Erkenntnis und Aufstieg. Einführung in die Philosofie von Edith Stein, InnsbruckWien-Würzburg, 1992, p. 44. Quoted: A. Półtawski, Personalizm fenomenologiczny: Edith Stein 
personalism which Edith Stein developed in her academic pursuits allows for "man's insight into his own being, a lively interest in knowing oneself which characterizes him as a spiritual being; and an ability to receive academic and cultural influences, which attest to his spirituality..."30.

The anthropological questions which Edith Stein raised, which she studied in her academic research, bring about a synthetic knowledge of man. That knowledge is not, however, exhaustive. Another constituent comes into it: to discover the truth about oneself, other people, and a personal God. It was precisely her research into discovering the truth about man, through empathy, in the experience of the other, which led her to successive discoveries. It might have seemed, however, that Edith Stein would go in the direction of a pure rationalism. Life proved otherwise, as Pope John Paul II so well expressed in his letter: "Yet it was precisely along the byways of philosophical investigation that grace awaited her: having chosen to undertake the study of phenomenology, she became sensitive to an objective reality which, far from ultimately dissolving in the subject, both precedes the subject and becomes the measure of subjective knowledge, and thus needs to be examined with rigorous objectivity. This reality must be heeded and grasped above all in the human being, by virtue of that capacity for "empathy" - a word dear to her - which enables one in some way to appropriate the lived experience of the other" 31 .

\section{The Discovery of God, the Highest Truth}

The Philosophical Society regularly invited Professor Max Scheler - whose lectures, in Stein's opinion, went far beyond the boundaries of philosophy - to Göttingen. Scheler was a believer, full of Catholic ideals, for which he could "find followers by the full glow of his spirit and the power of his speech. It was

i Karol Wojtyła [Phenomenological Personalism: Edith Stein and Karol Wojtyła], "Kwartalnik Filozoficzny" 1 (1995), p. 44.

${ }^{30}$ P. Secretan, Erkenntnis und Aufstieg. Einführung in die Philosofie von Edith Stein, InnsbruckWien-Würzburg, 1992, p. 44; Cf. M. Adamczyk, Edith Steins Weg zur Wahrheit, „Poznańskie Studia Teologiczne" 27 (2013), s. 99-105.

${ }^{31}$ John Paul II, List Motu Proprio ogłaszajacy św. Brygidę Szwedzka, św. Katarzynę ze Sieny i św. Teresę Benedyktę od Krzyża Wspótpatronkami Europy, 8; Cf. B. Szczepańska-Pabiszczak, Empatia jako forma komunikacji [Empathy as a Form of Communication], „Studia Kulturoznawcze” 1 (2011), p. 70-72; Cf. B. Beckmann-Zöller, H. Rainer Sepp (ed.), Edith Stein Gesamtausgabe. „Freiheit und Gnade" und andere Beiträge zu Phänomenologie und Ontologie: (1917 bis 1937), Freiburg 2014. 
- as Stein recalled - my first contacts with a world hitherto unknown to me. It still didn't lead me to faith, but it opened a certain area of 'the phenomenon' past which I could not pass blindly" 32 .

That same period gave her much to think about as she met Dr. Adolf Reinach, one of the closest associates of Prof. Edmund Husserl at Göttingen. Reinach set up a teaching circle at the University in which Stein was actively engaged. He and his wife evoked, as Stein put it, an "unusual impression" from her first encounter with them. "I was very happy and filled with a deep gratitude after that first conversation. It seemed to me that I had never before encountered someone of such goodness. I met here with something completely different. It was like a look into an entirely new world" ${ }^{33}$. It is worth noting here that the Reinachs were of Jewish descent but radiated faith in Christ $^{34}$.

Unfortunately, Dr. Reinach died in the First World War in 1917. As Stein herself recalled, her meetings with his widow were particularly moving. It was then that Stein noticed how the believing widow was able to draw hope and strength to go on living. She returned to that fact in this way: "That was my first encounter with the Cross and with the Divine strength that He gives to those who take it up. For the first time in my life I saw the victory of the Church over the sting of death" ${ }^{35}$. "That was when her unbelief collapsed and Christ revealed Himself in the mystery of the Cross" ${ }^{36}$. Edith Stein was gradually opening up to the acceptance of Christianity.

Another occurrence that gave Stein much to think about took place at the Cathedral of Freiburg. She entered the church for a few minutes. A moment later, in came another woman "weighed down by a basket, who knelt down in one of the pews for a brief prayer. This was something completely new to me. One went to synagogues and Protestant churches only for services. Here

${ }^{32}$ E. Stein, Światłość w ciemności [Light and Darkness], p. 126.

${ }^{33}$ E. Stein, Świattość w ciemności [Light and Darkness], p. 201.

${ }^{34}$ Cf. J. Seremak, Droga nawrócenia Edyty Stein [Edith Stein's Path to Conversion], http:// www.karmel.pl/hagiografia/stein/sympozja/baza.php?id=22 (08.10.2014).

${ }^{35}$ T. Rakoczy, Stowo pasterskie na obchody 70. lecia śmierci św. Teresy Benedykty od Krzyża (Edyty Stein), patronki Europy [Pastoral Letter on Marking the $70^{\text {th }}$ Anniversary of the Death of St. Teresa Benedicta of the Cross, Patroness of Europe] (07.31.2012) http://www.cdim.pl/pl/edukacja/ zasoby-edukacyjne/teksty/52-oficjalne-teksty-kocioa-katolickiego/476-bp-tadeusz-rakoczy-70leciesmierci-sw-edyty-stein (08.10.2014).

${ }^{36}$ E. Stein, Świattość w ciemności [Light and Darkness], p. 201. 
someone came to relax from the hustle and bustle of everyday life, and entered an empty church as if for a private conversation. I'll never forget that" ${ }^{\prime 37}$.

The next special occurrence on Stein's road searching for the truth was her reading of a book that surpassed other philosophical writings: the autobiographical "Life of St. Teresa of Avila". Stein wrote of her experience in reading the book: "I finished it in one reading. Upon closing it, I said to myself: 'This is the truth" "38. It was a turning point in her life. One can speak here of a gradual revolution that she interpreted as God's action which, through various experiences, led her to the Catholic faith that became her life. She decided to be baptized. This annotation was made in the Baptismal Book of the Bergzabern parish church: "In the year of Our Lord 1922, on January 1 Edith Stein, aged 30, doctor of philosophy, born 12 September 1891 in Wrocław, the daughter of Zygfryd Stein and Auguste Courant, was baptized. After good study and preparation, she passed from Judaism into the womb of the Church and received the name Terese Hedwig in baptism"39. From then on, faith and a relationship with the personal God became the center of her life as well as accompanying all her writing.

From the moment of her personal experience of the personal God, Edith Stein harmonized her life with the demands of the faith. She nourished it by meditating on Sacred Scripture and by experiencing the liturgy and sacraments deeply. As a scholar, she reached for Catholic philosophers and theologians - especially St. Thomas Aquinas and Henry Cardinal Newman - to read ${ }^{40}$. She drew much from St. Thomas' thought, whose ideas she then confronted with those of her master, Edmund Husserl. The result of that confrontation was her article, "The Phenomenology of Husserl and the Philosophy of St. Thomas Aquinas"41. She also translated Aquinas's work, Questiones disputatae De Veritate.

As she grew to discover Benedictine and Carmelite spirituality, she arrived at the conviction that God wanted her with the Carmelites, whom she joined in Cologne on October 14, 1933. There she met "the next master leading her on the path of longing for truth - St. John of the Cross. She had dealt with John's

${ }^{37}$ E. Stein, Świattość w ciemności [Light and Darkness], p. 176.

${ }^{38}$ E. Stein, Świattość w ciemności [Light and Darkness], p. 203.

39 J. Seremak, Droga nawrócenia Edyty Stein [Edith Stein's Path to Conversion], http://www. karmel.pl/hagiografia/stein/sympozja/baza.php?id=22 (08.12.2014).

${ }^{40} \mathrm{Cf}$. A. Chylewska, Zu Edith Steins memoiren und ihrem Briefwek, "Studies Germanica Posnaniensia" XXVII 2001, p. 141.

${ }^{41}$ Teresa Renata of the Holy Spirit (ed.), Edyta Stein, filozof i karmelitanka [Edith Stein, Philosopher and Carmelite], op. cit., p. 71. 
teaching already from postulancy out of purely religious reasons: she wanted to understand the spirituality of Carmel deeply in order to fulfill her Carmelite vocation to the fullest" ${ }^{\prime 2}$. With the Carmelites, she prepared to experience the dark night of faith, acceptance of the cross, and martyrdom. The Eucharist and the cross were her school leading her to the fullness of faith. Already in 1941, convinced of her approaching death she reached the following conclusion: "One can only gain the Scientia Crucis [the science of the Cross] if one has thoroughly experienced the cross. I have been convinced of this from the first moment onwards and have said with my entire heart: 'Ave, Crux, Spes unica' [Hail, O Cross, the Only Hope!]"43. When she made her first profession of vows as a "Bride of the Lamb" she believed that the "heavenly Bridegroom would lead her deeply into the mystery of the Cross" ${ }^{\prime 44}$. Her religious name meant "blessed by the Cross". Furthermore, her Way of the Cross was bound up with the fate of the Jewish People, evident from, among other things, her prayer, in which she confesses to the Divine Savior that "His Cross has now been placed on the Jewish people". All who can understand this, she says, "ought freely to take that cross upon themselves in the name of all. I wish to do that. He should only show me how" ${ }^{\prime 4}$.

In his Beatification Homily for Edith Stein, St. John Paul recalled an important point that is worth citing here: "Leaving the convent, Edith took her sister by the hand and said these few words: 'Come, we are going for our people'. With the power flowing from the imitation of Christ, an imitation to be fully prepared to sacrifice, she saw still one way - amidst her seeming weakness - to serve her people one last time. Already a few years earlier, she compared herself to Queen Esther in exile in the Persian court. In one of her

${ }^{42}$ J. Seremak, Droga nawrócenia Edyty Stein [Edith Stein's Path to Conversion], http://www. karmel.pl/hagiografia/stein/sympozja/baza.php?id=22 (08.12.2014). See W. Zyzak, Fundamentalna droga wiary w życiu i pismach św. Teresy Benedykty od Krzyża (Edyty Stein) [The Basic Path of Faith in the Life and Writings of St. Teresa Benedicta of the Cross (Edith Stein)], Kraków 2005.

${ }^{43}$ E. Stein, Świattość w ciemności [Light and Darkness], p. 283.

${ }_{44}$ John Paul II, Świadectwo błogosławionej Edyty Stein, siostry Benedykty od Krzyża-męczennicy [The Witness of Bl. Edith Stein-Sr. Benedicta of the Cross, Martyr], delivered during the beatification of Edith Stein in Cologne (05/01/1987) http://cdim.pl/pl/edukacja/zasoby-edukacyjne/teksty/52teksty-kocioa-katolickiego/74-1987-05-01-jan-pawe-ii-beatyfikacja-edyty-stein (06.08.2014).

${ }^{45}$ John Paul II, Świadectwo błogosławionej Edyty Stein, siostry Benedykty od Krzyża-męczennicy [The Witness of Bl. Edith Stein-Sr. Benedicta of the Cross, Martyr], delivered during the beatification of Edith Stein in Cologne (05/01/1987) http://cdim.pl/pl/edukacja/zasoby-edukacyjne/teksty/52teksty-kocioa-katolickiego/74-1987-05-01-jan-pawe-ii-beatyfikacja-edyty-stein (06.08.2014). 
letters, we read: 'I firmly trust that the Lord has accepted my life on behalf of all [Jews]. I keep thinking of Queen Esther, who had been taken from among her people in order for her to stand before the king for many. I am a very poor and powerless little Esther, but the King who has chosen me is infinitely great and merciful'" "46. Edith Stein died in the Auschwitz concentration camp as a daughter of the tormented Jewish nation and as a daughter of Carmel.

$$
* * *
$$

The search for truth was a passion in Edith Stein's life, the life of a wonderful woman and thinker, a great daughter of Israel and of Carmel. The honest search for truth through asking questions, and through use of the phenomenological method of 'empathy' with the other, led her to extraordinary discoveries, from disbelief in God to the experience of the Highest Truth, a personal God, who is Love, to the point of surrendering His Life on the Cross. She found that love is the freeest of everything that exists. "The saints who... decided to love their enemies heroically experienced the freedom of loving. Perhaps for a limited time the opposition of nature persists but it is powerless and incapable of influencing an attitude driven by supernatural love. Most often it gives way to the superabundance of the divine life that increasingly fills the soul. With regard to its ultimate sense, love is after all the surrender of one's own existence to the Beloved and union with Him. It is he who does the will of God who comes to know the Divine Spirit, the Divine Life, the Divine Love, i.e., God Himself. When one does this in the fullest surrender of self, then Divine Life becomes one's internal life: entering into one's self, one finds God in himself' ${ }^{\prime 47}$.

\section{Bibliography}

Adamczyk M., Edith Steins Weg zur Wahrheit, „Poznańskie Studia Teologiczne” 27 (2013), p. $91-106$.

Beckmann-Zöller B., Rainer Sepp H. (ed.), Edith Stein Gesamtausgabe. „Freiheit und Gnade” und andere Beiträge zu Phänomenologie und Ontologie: (1917 bis 1937), Freiburg 2014.

${ }^{46}$ John Paul II, Świadectwo błogosławionej Edyty Stein, siostry Benedykty od Krzyża-męczennicy [The Witness of Bl. Edith Stein-Sr. Benedicta of the Cross, Martyr], delivered during the beatification of Edith Stein in Cologne (05/01/1987) http://cdim.pl/pl/edukacja/zasoby-edukacyjne/teksty/52teksty-kocioa-katolickiego/74-1987-05-01-jan-pawe-ii-beatyfikacja-edyty-stein (06.08.2014).

${ }^{47}$ E. Stein, Byt skończony i byt wieczny [Limited Being and Eternal Being], Poznań 2005, p. 424. 
Będkowski M., Kazimierz Ajdukiewicz jako krytyk idealizmu subiektywnego, „Edukacja Filozoficzna" 55 (2013), p. 27-41.

Biela P., Einfühlung jako dialogiczność personalizmu fenomenologicznego Edith Stein, „Czasopismo Filozoficzne” 4/5 (2009), p. 115-135.

Chudy W., Filozofia klamstwa, Oficyna Wydawnicza Volumen, Warszawa 2003.

Chylewska A., Zu Edith Steins memoiren und ihrem Briefwerk, „Studies Germanica Posnaniensia" XXVII 2001, p. 131-141.

Enders M., Szaif J. (Hrsg.), Die Geschichte des philosophischen Begriffs der Wahrheit, Berlin 2006.

Gruszka F., Osoba i jej rozwój - wedlug Edyty Stein, in: K. Holeksa, E. Leśniewska, S. Leśniewski (eds.), Uderz o kamień a wytryśnie madrość. Rzecz o Edycie Stein, Wydawnictwo Karmelitów Bosych, Kraków 2002, p. 86-96.

Ingarden R., O badaniach filozoficznych Edith Stein, in: E. Stein, O zagadnieniu wczucia, trans. D. Gerulanka and JF Gerula, Wydawnictwo Znak, Kraków 1988, s. 155-181.

Jan Paweł II, List Motu Proprio ogłaszający św. Brygidę Szwedzka, św. Katarzynę ze Sieny i św. Teresę Benedyktę od Krzyża Wspótpatronkami Europy (10/01/1999),

http://www.opoka.org.pl/biblioteka/W/WP/jan_pawel_ii/motu/patronki_europy.html\# (08.10.2014).

John Paul II, Świadectwo blogosławionej Edyty Stein, siostry Benedykty od Krzyża - męczennicy, delivered during the beatification of Edith Stein in Cologne (05.01.1987) http://cdim.pl/ pl/edukacja/zasoby-edukacyjne/teksty/52-teksty-kocioa-katolickiego/74-1987-05-01-janpawe-ii-beatyfikacja-edyty-stein (08.06.2014).

Kotłowska A., Fenomenologiczna myśl antropologiczna Edyty Stein, „Fenomenologia” 8 (2010), p. 63-79.

Maisner J., Homilia z okazji 70. Rocznicy śmierci św. Edyty Stein w Auschwitz (09.08.2012), Edukacja, Centrum Dialogu i Modlitwy w Oświęcimiu, www.cdim.pl (08.05.2014).

Machnacz J., Odnaleźć siebie, drugiego, Boga. Antropologia Edyty Stein, in: J. Pater (eds.), Odnaleźć siebie, drugiego, Boga. Antropologia Edyty Stein, Wydawnictwo Papieskiego Wydziału Teologicznego, Wrocław 2005, p. 15-27.

Półtawski A., Personalizm fenomenologiczny: Edith Stein i Karol Wojtyła, „Kwartalnik Filozoficzny" 1 (1995), p. 33-44.

Rakoczy T., Stowo pasterskie na obchody 70. lecia śmierci św. Teresy Benedykty od Krzyża (Edyty Stein), patronki Europy (07.31.2012), http://www.cdim.pl/pl/edukacja/zasobyedukacyjne/teksty/52-oficjalne-teksty-kocioa-katolickiego/476-bp-tadeusz-rakoczy70lecie-smierci-sw-edyty-stein (08.10.2014).

Secretan P., Erkenntnis und Aufstieg. Einführung in die Philosofie von Edith Stein, Echter Würzburg, Innsbruck-Wien-Würzburg 1992.

Seremak J., Droga nawrócenia Edyty Stein, http://www.karmel.pl/hagiografia/stein/sympozja/ baza.php?id=22 (08.10.2014).

Stein E., Byt skończony i byt wieczny, trans. I. J. Adamska, Wydawnictwo W drodze, Poznań 2005.

Stein E., O zagadnieniu wczucia, trans. D. Gerulanka and J.F. Gerula, Wydawnictwo Znak, Kraków 1988.

Stein E., Świattość w ciemności, vol. 1, trans. I. J. Adamska, Wydawnictwo Karmelitów Bosych, Kraków 1977. 
Stępień A. B., Wstęp do filozofii, Towarzystwo Naukowe KUL, Lublin 1976.

Szczepańska-Pabiszczak B., Empatia jako forma komunikacji, „Studia Kulturoznawcze” 1 (2011), p. 69-78.

Teresa Benedicta of the Cross (Edith Stein), Dzieje pewnej rodziny żydowskiej, Wydawnictwo Karmelitów Bosych, Kraków 1995.

Teresa Renata of the Holy Spirit (ed.), Edyta Stein, filozof $i$ karmelitanka, tłum. M. Kaczmarkowski, Editions du dialogue, Paris 1987.

Zyzak W., Fundamentalna droga wiary w życiu i pismach św. Teresy Benedykty od Krzyża (Edyty Stein), Wydawnictwo ITKM, Kraków 2005. 
